\title{
Optimization of fleet structure and investment evaluation - the cargo owner's fleet perspective
}

\author{
Zhihong Jin, Xiaohan Wang and Jiaqing Sun \\ College of Transportation Engineering, Dalian Maritime University, \\ Dalian, China, and \\ Qi Xu \\ School of Architecture and Transportation Engineering, \\ Guilin University of Electronic Technology, Guilin, China
}

\begin{abstract}
Purpose - Energy groups are cargo owners with large amounts of energy sources (such as coal) to transport. To achieve a satisfactory tradeoff between the reliability requirements of the sea transportation process and the need to control the investment cost, they usually set up a self-owned fleet supplemented by a chartered fleet. This paper aims to investigate the best fleet structure and to evaluate the investment scheme under volatile circumstances in the shipping market.

Design/methodology/approach - The authors construct a mathematical model to determine the ratio of the self-owned fleet to the total fleet to minimize fleet operating costs. The volatility of both freight rates and oil prices is taken into consideration. The CPLEX solver is used to empirically analyze real data from an energy group in China, and the ship investment plan is evaluated considering the technical and economic feasibility. Findings - If the ratio of the self-owned fleet to the total fleet is increased to the optimal of $90.40 \%$, the total operating cost is reduced by $33.98 \%$. Thus, the energy group should increase its capacity with a Panamax vessel of approximately 82,000 DWT. Purchasing a 5-year-old secondhand ship and building a new ship both have good investment return indicators.

Originality/value - For cargo owners engaging in transporting bulk cargo domestically in China, the suggested fleet ratio can provide a reference with a universal application scale, given the boundary economic conditions (including the volatility of freight rates and oil prices in the shipping market) in the paper.
\end{abstract}

Keywords Electricity coal, Cargo owner's fleet, Self-owned fleet ratio, Fleet development, Investment evaluation

Paper type Research paper

\section{Introduction}

In the global dry bulk transportation market, coal is the second largest dry bulk after iron ore. Electricity coal transportation is related to the national economy and people's livelihood. To ensure a stable supply of coal for power plants, energy groups usually establish self-owned fleets. In terms of safety, economy, security, flexibility and compliance, self-owned ships have absolute advantages over chartered ships.

An energy group must ensure the normal supply of electricity coal while improving operating efficiency. Determining an appropriate ratio of its self-owned fleet to chartered fleet, reducing the volatility of the overall fleet model and confirming the fleet development model are important decisions a cargo fleet owner must make.

(C) Pacific Star Group Education Foundation. Licensed re-use rights only.

The authors would like to express their gratitude for the support provided by the National Natural Science Foundation of China (grant numbers 72172023, 72171037, 71702019 and 71861006), Natural Science Foundation of Liaoning Province, China (grant number 2020HYLH4) and Fundamental Research Funds for the Central Universities of Ministry of Education of China (grant number 3132019301).

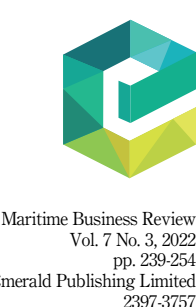

2397-3757 
MABR

7,3

240

Scholars have focused on transportation demand forecasting for dry bulk. Modern heuristic optimization algorithms, including particle swarm optimization (PSO) and genetic algorithms (GAs) (Yu and Zhu, 2012; Yu et al., 2012); machine learning methods, including vector autoregressive models (VARs) (Li et al., 2015) and long short-term memory (LSTM) (Sozen et al., 2021); and neural networks (Yu et al., 2012; Li et al., 2015; Sozen et al., 2021; Wang et al., 2018; Lee and Chiu, 2013), have been introduced to scientifically predict the demand for dry bulk.

In terms of coal transportation research, Wu et al. (1995) and Liu and Sherali (2000) built a 0-1 mixed integer programming (MIP) model to investigate the problem of sea transportation of coal and solved the model with intelligent optimization algorithms, including branch and bound, Benders decomposition and GA. Wang et al. (2018) revealed the spatial pattern and temporal evolution of coal transportation along coastal ports in China. Considering costs and technical parameters, Ozfirat et al. (2018) evaluated alternative transportation modes in the transportation process of coal via the fuzzy analytic hierarchy process (FAHP). Yucekaya (2013) developed a multi-objective model to decide the supplier, transportation mode and coal order for coal power plants. Cigolini et al. (2013) proposed a simulation model to determine the number of barges, barge capacity and crane rates. In addition, some works have focused on railway coal transportation (Sherwood et al., 2020; Li and Liao, 2018; Zhu and Zhang, 2020).

The network structure of coal transportation, including cargo flow distribution, route optimization and facility configuration, has also been studied extensively. Wang et al. (2018) revealed the spatial pattern and temporal evolution of coal transportation along coastal ports in China. Mon and Li (2012) investigated the distribution of coal resources in China's coal transportation network, and a linear optimization model was developed. Referring to the modeling ideas of complex networks, Wang and Li (2019) studied the spatial evolution of the coal transportation network of China, and they concluded that the coal transportation of China is highly concentrated. Further research was performed by Wang and Li (2020), who proposed a hub-and-spoke network structure of China's domestic coal transportation. Wang and Ducruet (2014) held that the coal demand is seriously imbalanced in coastal and inland areas of China; therefore, the construction of coal transportation transfer hubs should be increased.

Scholars have built optimization models to study fleet planning issues, mainly from the perspectives of route allocation and route ship type selection. Considering the chartering mode and improved optimization algorithms, Xie et al. (2014) established a model for route allocation and fleet planning to minimize the total cost of the fleet during the planning period. Wang et al. (2016) proposed a maximum and minimum regret value model for fleet deployment based on uncertain demand. Tierney et al. (2017) presented a multi-objective programming model based on simulated annealing (SA) to optimize the relocation of liner fleets. The study realized cost savings and environmental sustainability simultaneously. Meng et al. (2015) presented the continuous programming problem of container liner fleets. Considering uncertain freight demand conditions, they established a multiperiod stochastic planning model that can be solved by means of a hybrid algorithm combined with dual decomposition and Lagrangian relaxation. To maximize the profits of the shipping company, Jiang et al. (2019) and Yang et al. (2019) formulated a renewal scheme (including a construction plan and dismantling plan) for dry bulk ships with or without subsidies. Alvarez et al. (2011) proposed a multi-period MIP model to solve the fleet sizing and deployment problem. To account for inherent uncertainty, the MIP model was extended to a robust optimization model.

After reviewing the relevant literature on dry bulk fleet programming, we find that the allocation of transport capacity has not been addressed. For dry bulk shipping companies, especially for cargo owners' fleets, rational adjustment of the allocation ratio of various fleet modes is important for formulating the number and types of ships. However, the existing literature ignores this factor, not to mention the consideration of the volatility of oil prices and freight rates. However, the shipping market is characterized by extreme volatility. Taking the Baltic Dry Index (BDI) in the past two decades as an example, the value at peak is more than 10 times the value at the trough point, as shown in Figure 1 . Thus, it is necessary to provide 


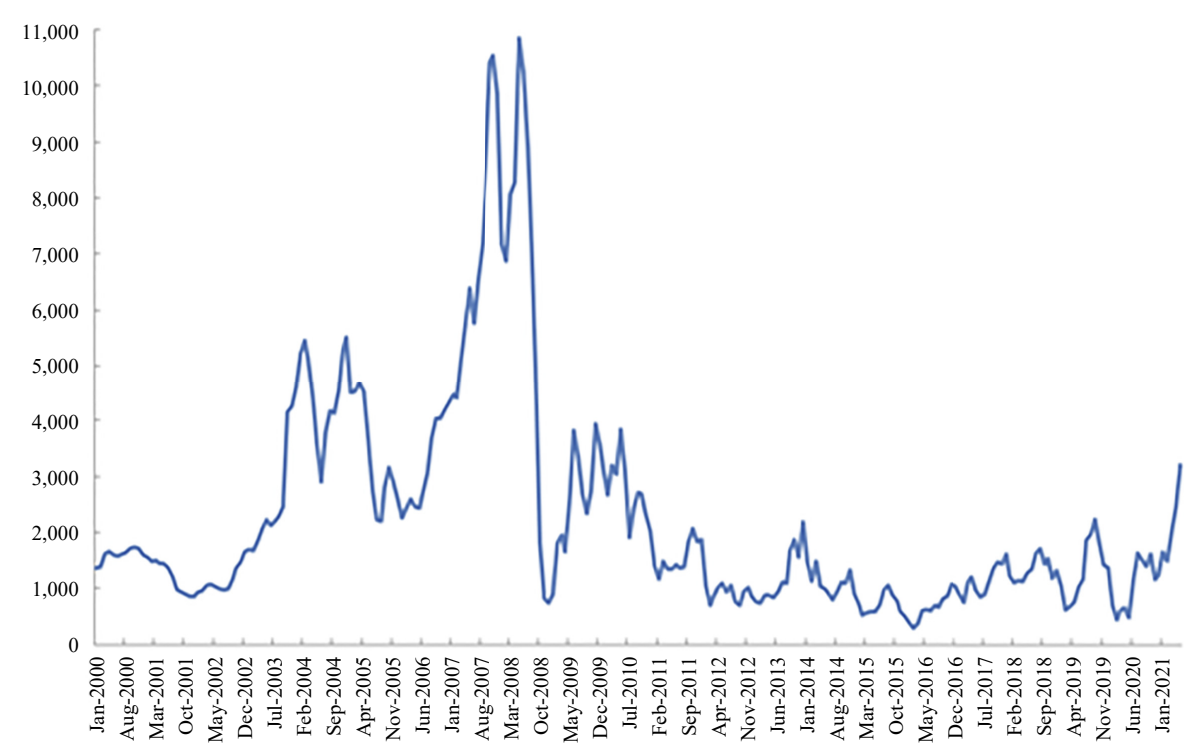

Source(s): The Baltic and International Maritime Council

practical suggestions for the cargo owner's fleet in terms of the proportion of the self-owned fleet to the total fleet while considering various sources of volatility, such as freight rates and oil prices. In addition, few scholars have analyzed the economic and technical feasibility of fleet development plans. These analyses have highly practical significance for the implementation of dry bulk shipping companies' fleet planning schemes.

This paper makes two main contributions.

(1) Considering the real needs of cargo owners' fleets, intelligent optimization theory is used to study the rational composition of the self-owned fleet mode and chartered fleet mode to minimize the total operating cost. The optimal ratio of the self-owned fleet that we propose in this paper in consideration of volatile factors in the shipping market provides a universal reference for cargo owners' fleet development schemes both practically and theoretically.

(2) Based on the estimated demand of electricity coal from the energy group and the optimal fleet composition, the best fleet development plan, including the number and type of ships and the investment mode, is determined from the two perspectives of technical and economic feasibility. Therefore, a feasible bulk cargo carrier investment plan can be achieved, together with a sensitivity analysis including freight rates, oil prices, ship prices and exchange rates (US dollars to Chinese yuan).

The paper is organized as follows. The fleet composition model is presented in Section 2, and computational experiments are conducted in Section 3. In Section 4, we describe the detailed economic and technical evaluation of different development schemes for the self-owned fleet. Finally, Section 5 draws the main conclusions.

\section{Model formulation for the fleet combination schema}

In the following research, we focus on the setup of bulk cargo fleets for domestic trade transportation. To maintain stable transportation of electrical coal, the energy group should 
MABR 7,3

\section{2}

adopt an independent development pattern composed mainly of a self-owned fleet, supplemented by a charter fleet.

The goal of the fleet allocation plan is to meet the needs of electricity coal transportation while minimizing fleet operating costs. Therefore, considering the volatility characteristics of demand, opportunity loss, oil prices, freight rates and other factors, we establish an optimization model to obtain the best allocation ratio of the self-owned fleet to the total transport requirements. The logic of the modeling process is shown in detail in Figure 2.

To ensure the supply of electricity coal, the fleet typically has a higher proportion of ships waiting for cargo and with empty loads on the outbound journey, which indirectly increases the operating costs. If the fleet obtains ineffective operating time and capacity in the dry-bulk market to contract social freight sources, it will receive only part of the potential income, that is, opportunity loss. Therefore, we define the parameter $\mu_{t}$ to express opportunity loss.

\subsection{Model assumptions}

The following two assumptions are made in the mathematical formulation:

(1) The operating routes of electricity coal are known and implemented following established operating requirements;

(2) The fleet capacity is divided into a self-owned fleet and chartered fleet, and the former accounts for the majority of the fleet capacity. The capacity is supplemented by chartering only when the self-owned fleet is insufficient.

\subsection{Notation}

Notations are mentioned below:

Sets and indices
$O$
$D$
$T$
$S$
Parameters
$q_{o, d}^{t}$
$\gamma_{s}$
$l_{s}$
$w_{t}$
$G_{s}$
$K$
$\Gamma_{t}$
$\delta_{s t}$
$\left\{c_{t s}^{1}, c_{t s}^{2}, c_{t s}^{3}, c_{t s}^{4}, c_{t s}^{5}, c_{t s}^{6}, c_{t s}^{7}\right\}$
$\left\{c_{t o}^{8}, c_{t d}^{9}\right\}$
$\chi_{t}^{1}$
$\chi_{t}^{2}$
$\mu_{t}$
$\tilde{\xi}_{t}^{1}$

set of electricity coal loading ports, $o \in O$

set of electricity coal unloading ports, $d \in D$

set of operating years, $t \in T$

set of owned ships, $s \in S$

annual average demand of electricity coal from loading port $o$ to unloading port $d$ in the $t$ th year

estimated residual value rate of ship $s$

estimated available life of ship $s$

actual cargo capacity of own fleet in the $t$ th year

purchasing price of ship $s$

average cargo carrying capacity of unit owned fleet

average voyage time of unit own fleet in the $t$ th year

indicator of whether the ship is still in operation in the $t$ th year

ship's operating costs in the $t$ th year, representing the crew's wages, insurance

premiums, insurance and indemnity fees, ship maintenance fees, ship

moisturizing fees, ship material fees and management fees in the th year

port charges of the loading port and the unloading port in the $t$ th year

refueling amount of heavy oil in the $t$ th year

refueling amount of light oil in the $t$ th year

opportunity loss ratio of own fleet in the $t$ th year

expected price of heavy oil in the $t$ th year

(continued) 
$\tilde{\xi}_{t}^{2}$
$\tilde{F}_{t}$

\section{Decision variable}

$R_{t}$

\section{Derived variables}

$C_{t}^{1}$

$C_{t}^{2}$

$C_{t}^{3}$

$C_{t}^{4}$

$C_{t}^{5}$

$x_{t}$

$y_{t}$

$\eta_{t}$ expected price of light oil in the $t$ th year

expected coal freight rate in the $t$ th year

proportion of self-owned fleet capacity in year $t$

annual capital cost of self-owned ship operating costs of self-owned ship in the $t$ th year voyage costs of self-owned ship in the $t$ th year rental cost of chartered vessels in the $t$ th year opportunity loss for self-owned capacity in the $t$ th year optimal capacity of electricity coal for self-owned fleet in year $t$ optimal capacity of electricity coal for chartered ships in year $t$ optimal number of ships in the self-owned fleet in year $t$

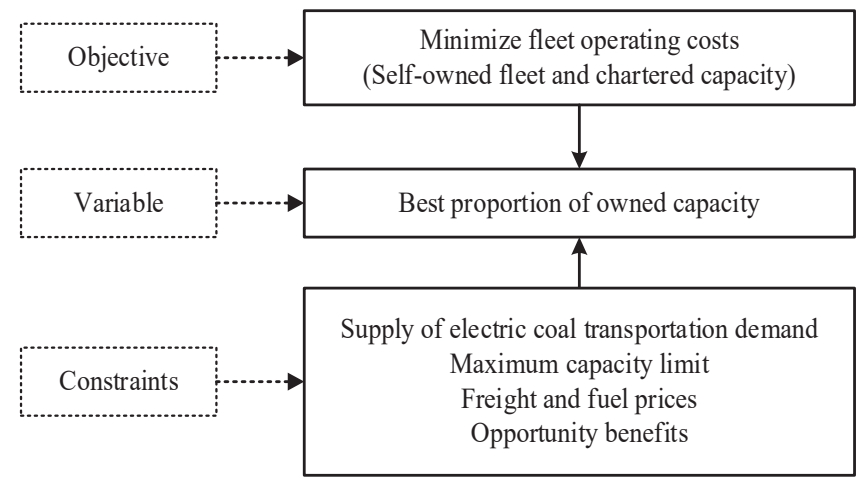

Figure 2.

Logical diagram of the fleet allocation model

\subsection{Mathematical model}

(1) Objective

$$
\begin{gathered}
C_{t}^{1}=x_{t}\left\{\frac{\sum_{s \in S} \delta_{s t} G_{s}\left[\left(1-\gamma_{s}\right) / l_{s}\right]}{w_{t}}\right\} \\
C_{t}^{2}=x_{t}\left(\frac{\sum_{s \in S} \delta_{s t}\left(c_{t s}^{1}+c_{t s}^{2}+c_{t s}^{3}+c_{t s}^{4}+c_{t s}^{5}+c_{t s}^{6}+c_{t s}^{7}\right)}{w_{t}}\right) \\
C_{t}^{3}=\frac{\tilde{\xi}_{t}^{1} \chi_{t}^{1}+\tilde{\xi}_{t}^{2} \chi_{t}^{2}}{w_{t}} x_{t}+\frac{\sum_{o \in O} c_{t o}^{8}+\sum_{d \in D} c_{t d}^{9}}{w_{t}} x_{t} \\
C_{t}^{4}=\left(1-R_{t}\right) \sum_{o \in O} \sum_{d \in D} \tilde{F}_{t} q_{o d}^{t} \\
C_{t}^{5}=\mu_{t} x_{t} \tilde{F}_{t}
\end{gathered}
$$


Equation (6) is the objective of the verification model for the allocation ratio to minimize the operating costs of the dry-bulk fleet, including the transportation cost of the self-owned fleet and the rental cost of chartered ships, while opportunity income for guaranteeing the supply is taken into account. Equations (1)-(3) calculate the capital cost, fixed operating cost and variable voyage cost of self-owned ships. Equation (4) is the rental cost. Equation (5) expresses the opportunity income of transporting social cargo for a self-owned fleet to meet the transportation needs of electricity coal.

(2) Constraints

$$
\begin{gathered}
x_{t}+y_{t}=\sum_{o \in O} \sum_{d \in D} q_{o d}^{t}, \forall t \in T \\
x_{t}=R_{t} \cdot \sum_{o \in O} \sum_{d \in D} q_{o d}^{t}, \forall t \in T \\
y_{t}=\left(1-R_{t}\right) \cdot \sum_{o \in O} \sum_{d \in D} q_{o d}^{t}, \forall t \in T \\
x_{t} \leq \frac{365}{\Gamma_{t}} \cdot \eta_{t} \cdot K \\
C_{t}^{i} \geq 0, \forall t \in T, i=\{1,2,3,4\} \\
R_{t} \in[0,1], \forall t \in T \\
x_{t} \geq 0, u_{t} \geq 0, \forall t \in T \\
\eta_{t} \in Z \cup\{0\}
\end{gathered}
$$

Equation (7) indicates that the transportation needs of electricity coal must be met. Equations (8) and (9) represent the relationship between the volume of the self-owned fleet, the volume of chartered ships and the decision variables. Based on the number of voyages completed by the self-owned fleet each year, equation (10) reflects the relationship between the optimal transport capacity and the optimal number of ships. Equations (11)-(14) define the variables.

\section{Computational experiments}

The optimization model is a mixed-integer linear programming problem that can be solved by ILOG CPLEX 12.6.2. Moreover, the correctness of the model and the accuracy of the experimental results can be verified. The computing environment is an Intel®Core ${ }^{\mathrm{TM}}$ i77700CPU@3.60 GHz processor and 8 GB memory.

\subsection{Experimental design}

The numerical experiments are based on real data from an energy group in China. The company has four vessels operating in the domestic electricity coal trade. The calculation of ship capital costs adopts the straight-line depreciation method, and the salvage value is $5 \%$ of the shipping price. The average cargo capacity is $95 \%$ of the average deadweight tonnage of the four ships, i.e. 73,149 tons. The opportunity loss ratio is set to 0.5 . According to the Chinese shipping market situation in the past ten years, the expected coal freight rate is set to 48 yuan/ton, and the oil price is set to 3,788 yuan/ton (http://www.cqcoal.com/exp/ocfi.jsp; 
https://www.cn-eship.com/). Considering data confidentiality, other detailed data are not included here.

\subsection{Experimental results}

Based on the operational data of the energy group from 2016 to 2020, we can calculate the optimal capacity allocation ratio from 2016 to 2020, as shown in Table 1.

According to Table 1, in the past five years, the optimal average capacity allocation ratio was $90.40 \%$, while the actual ratio was only $68.96 \%$. From 2016 to 2020 , the annual capacity ratio did not reach the optimal value. The largest gap between the optimal ratio and the actual ratio of $34.80 \%$ occurred in 2018 . Therefore, to reduce the operating costs and achieve the group's requirements for ensuring the supply of electricity coal, the allocation of the dry bulk fleet should be further improved.

In 2016 and 2020, the proportion of the optimal fleet allocation for dry bulk was relatively small, while the proportion of chartered ships was relatively large. The reason is that the dry bulk market was relatively sluggish in those years, and the coal freight rate was low. According to the experimental results, the optimal capacities of the self-owned fleet and chartered vessels from 2016 to 2020 are shown in Figure 3.

Under the optimal transport capacity ratio in Table 1, the total operating cost is 844 million yuan, of which the operating cost of the self-owned fleet is 751 million yuan, and the rent of the charter fleet is 91.9 million yuan. With the current fleet ratio, the actual total operating cost in the past five years is 1.28 billion yuan, of which the operating cost of the self-owned fleet is 913 million yuan, and the rent is 363 million yuan. Therefore, if the energy group increases the self-owned fleet ratio to the optimal value, the total operating cost can be reduced by $33.98 \%$.

\begin{tabular}{|c|c|c|c|c|c|c|c|}
\hline Year & 2016 & 2017 & 2018 & 2019 & 2020 & Average & \\
\hline Optimal ratio & $80.58 \%$ & $95.11 \%$ & $90.56 \%$ & $100 \%$ & $85.74 \%$ & $90.40 \%$ & Optimal capacity \\
\hline Actual ratio & $70.24 \%$ & $63.16 \%$ & $55.76 \%$ & $81.25 \%$ & $74.39 \%$ & $68.96 \%$ & allocation ratio for \\
\hline Gap & $10.34 \%$ & $31.95 \%$ & $34.80 \%$ & $18.75 \%$ & $11.35 \%$ & $21.44 \%$ & 2016-2020 \\
\hline
\end{tabular}

The cargo owner's fleet perspective

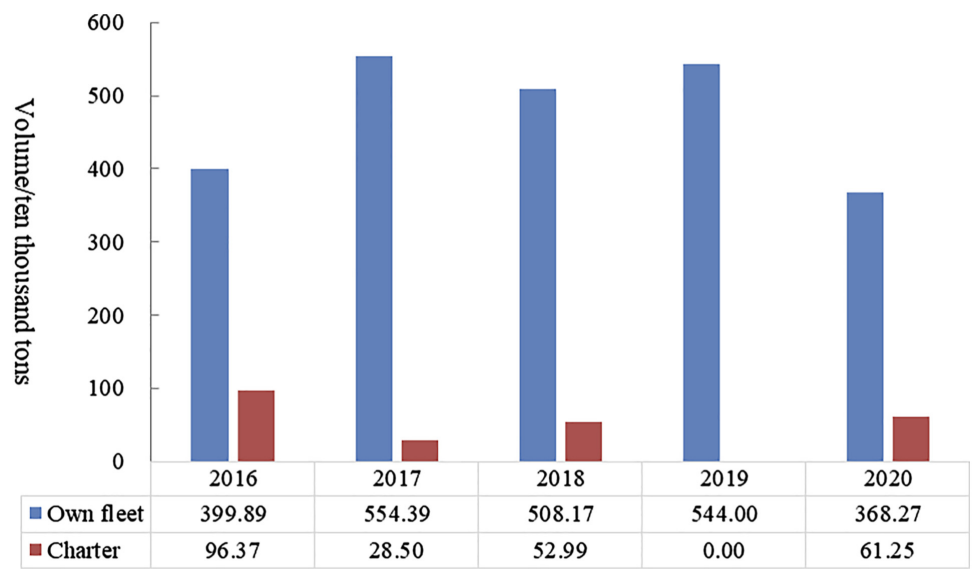

Figure 3.

The optimal volumes of the self-owned fleet and chartered ships from 2016 to 2020 
MABR

7,3

\section{6}

\subsection{Sensitivity analysis}

(1) The impact of a decrease in capital cost on the results

Purchasing ships at high prices is the main factor leading to high operating costs. Thus, we select the capital cost for a sensitivity analysis. Assuming that the opportunity loss ratio of the self-owned fleet is very small at 0.1 , the capital cost is selected as the influencing factor for the sensitivity analysis, and the optimal proportion of the self-owned fleet is shown in Figure 4.

The optimal proportion of the self-owned fleet gradually increases as the capital cost decreases. When the capital cost drops by $40 \%$, even if the opportunity loss ratio is low, the optimal proportion of the self-owned fleet is still greater than $90 \%$. Compared with higher purchase costs in the original data (the original four-ship fleet was purchased in 2008 , which was the turning point from the peak to trough in the shipping market), a $40 \%$ reduction in capital cost can be easily achieved in the current dry bulk shipping market.

(2) The impact of the opportunity loss ratio and the average DWT of the self-owned fleet on the results

To verify the validity and universality of the model and to provide a flexible fleet allocation recommendations, two factors are selected for a sensitivity analysis: the opportunity loss ratio and the average DWT per ship of the self-owned fleet. The results are shown in Figures 5 and 6.

Figure 5 shows the impact of two factors on the configuration ratio of the self-owned fleet. Overall, the proposition of transport capacity allocation is positively correlated with the ratio of opportunity loss, but it is not monotonously increasing. When the latter increases to a certain value, the former will no longer change. For example, if the average cargo capacity is 65,000 tons, the opportunity loss ratio is greater than 0.6 , which may ensure the largest proportion of the self-owned fleet allocation. Under the same opportunity loss ratio, the larger the average cargo capacity is, the greater the proportion of the self-owned fleet allocation.

Figure 6 illustrates the impact of two factors on the total operating costs. Contrary to the expression in Figure 5, the total operating costs are negatively correlated with the opportunity loss ratio and are monotonically decreasing. However, the impact of the average cargo capacity on operating costs differs under different opportunity loss ratios. When the ratio is in the range of [0, 0.2], as the average cargo capacity increases, the total operating cost

Figure 4.

The impact of a decrease in capital cost on the optimal proportion of the self-owned fleet

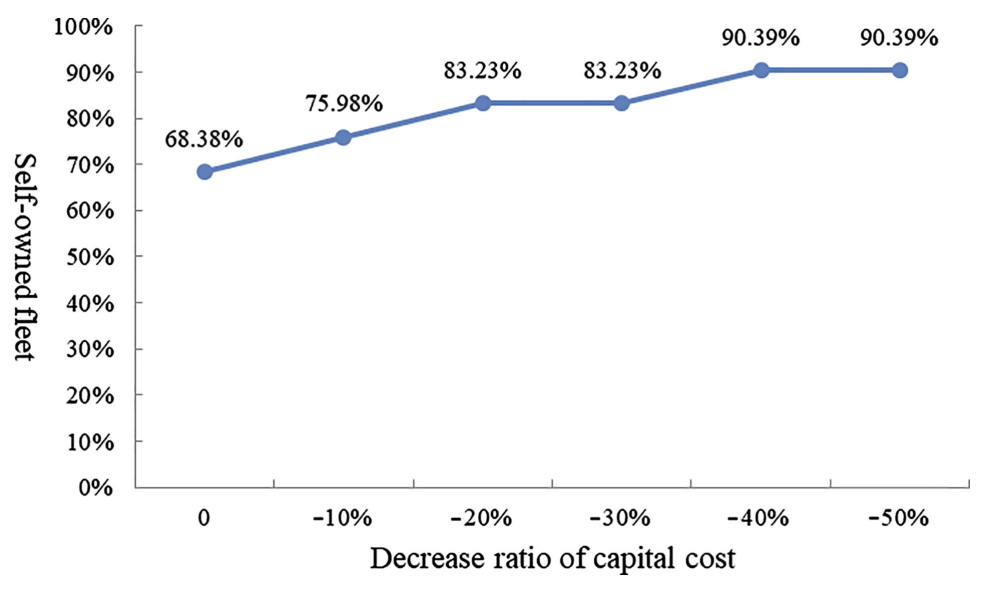



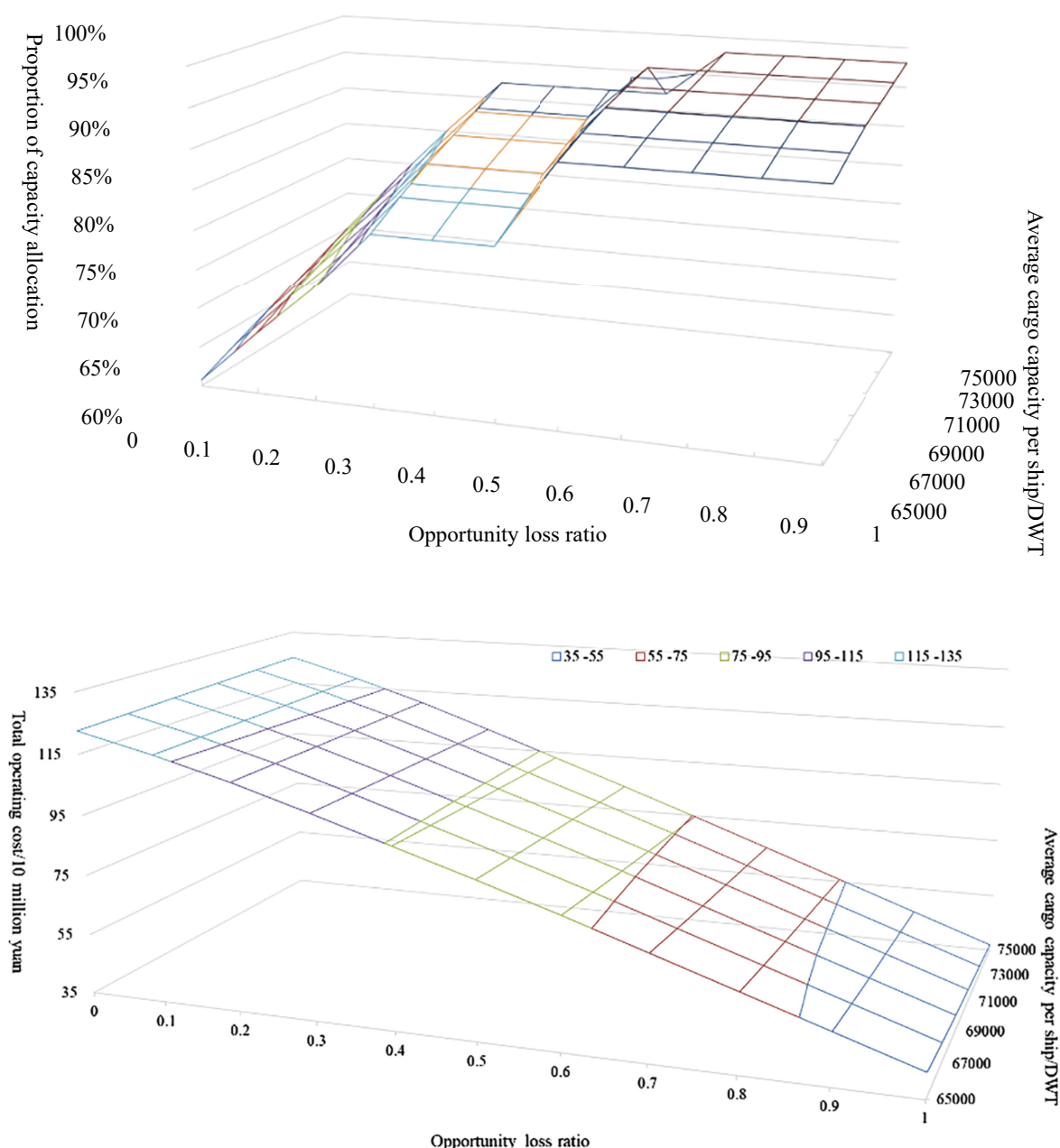

Figure 6 .

The operating costs in different scenarios

gradually increases. When the ratio is in the range of $[0.3,1]$, the latter decreases as the former increases. Therefore, in most circumstances, the energy group should choose larger ships to achieve economies of scale.

\section{Evaluation of the development plan of the self-owned fleet}

\subsection{Quantity and type of bulk carriers}

Based on the verification model of fleet allocation proportion, the optimal transport capacity proportion of the self-owned fleet is $90.40 \%$, while the actual proportion is only $68.96 \%$. According to equation (10), the optimal number of self-owned vessels can be obtained via equation (15). 
MABR

7,3

\section{8}

Table 2.

Optimal quantity of self-owned vessels under various deadweights

$$
\eta_{t} \geq \frac{x_{t} \cdot \Gamma_{t}}{365 \cdot K}
$$

Considering the economies of scale of vessels, we assume that the deadweight tonnage (DWT) of newly purchased vessels is between 76,000 and 96,000. The available cargo capacity of the vessel is $95 \%$ of the deadweight, and the annual operating time ratio is $95 \%$. Based on the predicted value of domestic trade for electricity coal during 2021-2025 and the optimal transport capacity proportion of self-owned vessels, we calculate the optimal quantity of ships, as shown in Table 2.

The larger the DWT of newly purchased ships is, the smaller the number of vessels required. According to Table 2, the optimal allocation quantity of vessels in 2021 is less than 5 ; however, the optimal number in other years is more than 5. If six ships are allocated for a self-owned fleet, the loss rate of the fleet will increase significantly; therefore, the optimal quantity of the self-owned fleet is 5 .

The current mainstream bulk carrier in the short-sea shipping market is the Super Panamax at approximately 82,000 DWT. The previous Panamax (approximately 76,000 DWT) is no longer produced by shipyards, and there are very few in the secondhand ship market. If a larger ship type is selected, for example, more than 90,000 DWT, it may cause more breakage. In addition, considering the technical conditions and handling capacity of loading and unloading ports of electricity coal, ships of more than 90,000 tons cannot meet the requirements. Combined with the current situation of domestic terminals and ports, the electric coal transportation demand of the energy group, and the development trends of the shipping market, the Panamax vessel with 82,000 DWT is recommended and is used as an example in the following economic analysis.

According to the forecasted electricity coal demand from the energy group in 2021-2025, the average DWT of five self-owned vessels with the newly purchased vessel at approximately 82,000 DWT is 75,513 tons. The transport capacity of the self-owned fleet in 2021-2025 can be found in Table 3 .

As shown in Table 3 , the average loading capacity of the self-owned fleet accounts for $86.60 \%$ when the newly purchased 82,000 DWT vessel is included, which is slightly less than the optimal value of $90.04 \%$. However, if two new Panamax ships are added, the ratio of the self-owned fleet is excessive, which will lead to a large breakage.

\begin{tabular}{lrrrrrc}
\hline & 2021 & \multicolumn{1}{c}{2022} & \multicolumn{1}{c}{2023} & \multicolumn{1}{c}{2024} & 2025 & Average \\
\hline Domestic trade/10 thousand tons & \multicolumn{1}{c}{541.4} & \multicolumn{1}{c}{634.5} & 621.09 & 608.22 & 595.83 & \multicolumn{1}{c}{-} \\
Optimal transport capacity/ton & 489.43 & 573.59 & 561.47 & 549.83 & 538.63 & \multicolumn{1}{c}{5.31} \\
Number of ships (76,000 DWT) & 4.79 & 5.62 & 5.50 & 5.39 & 5.28 & 5.24 \\
Number of ships (82,000 DWT) & 4.72 & 5.53 & 5.42 & 5.30 & 5.19 & 5.13 \\
Number of ships (90,000 DWT) & 4.62 & 5.42 & 5.30 & 5.19 & 5.09 & 5.05 \\
Number of ships (96,000 DWT) & 4.55 & 5.34 & 5.22 & 5.12 & 5.01 & 5.05 \\
\hline
\end{tabular}

Table 3.

Transport capacity proportion of the selfowned fleet with the newly purchased 82,000 DWT vessel

\begin{tabular}{lccccc}
\hline & 2021 & 2022 & 2023 & 2024 & 2025 \\
\hline $\begin{array}{l}\text { Estimated domestic demand for electric coal/ten } \\
\text { thousand tons }\end{array}$ & 541.4 & 634.5 & 621.09 & 608.22 & 595.83 \\
$\begin{array}{l}\text { Average loading capacity of self-owned fleet/ten } \\
\text { thousand tons }\end{array}$ & 518.23 & 518.23 & 518.23 & 518.23 & 518.23 \\
Capacity ratio of self-owned fleet & $95.72 \%$ & $81.67 \%$ & $83.44 \%$ & $85.20 \%$ & $86.98 \%$
\end{tabular}




\subsection{The investment scheme of the bulk carrier}

4.2.1 Preselection of an investment scheme. Since the fourth quarter of 2020, China's coastal dry bulk market has picked up and shown a positive trend. At present, it is difficult for the shipbuilding market and ship trading market to find suitable newly constructed ships for sale on commission. Therefore, we consider only constructing a new ship and buying secondhand ships for the fleet development plan. According to industry practices, the secondhand ship market usually divides ships according to age, such as 5-year-old ships, 10-year-old ships and 15-year-old ships.

Ships older than 15 years are typically characterized by poor condition, high fuel consumption, poor seaworthiness and low safety. Therefore, from the perspective of fleet competitiveness, ships more than 15 years old are not considered. In addition, ships built before 2011 do not meet Tier II emission requirements issued by the IMO. Furthermore, it is also unreasonable to buy a secondhand vessel that is approximately 10 years old. Therefore, our preselected investment plan includes two options, i.e. the construction of a new ship and the purchase of a 5-year-old secondhand ship.

\subsubsection{Economic indicators for the two fleet development plans.}

(1) Basic financial evaluation data

The main assumptions of the financial evaluation are shown in Table 4. Since the fourth quarter of 2020, the dry bulk shipping market has gradually improved, driving the recovery of the shipbuilding market and the secondhand ship trading market, and ship transaction prices have risen accordingly. For ship transaction prices, we refer to Clarkson's research report and retain a certain amount of surplus space simultaneously.

(2) Economic indicators for the two fleet development plans

On the basis of the basic premise above, a comparative analysis of the economic indicators of two fleet development plans is shown in Table 5.

\begin{tabular}{lll}
\hline Item & & Numerical value \\
\hline Ship price (ten thousand US dollars) & New ship & 3,150 \\
& 5-year-old ship & 2850 \\
Ship purchase tax rate (tariff + value-added tax) & $23.17 \%$ \\
Freight rate (yuan/ton) & 48 yuan/ton \\
Discount rate & $8 \%$ \\
Vessel depreciation & Depreciation period (year) & Completed 8 years ahead of schedule \\
& Residual value rate & $5 \%$ \\
Exchange rate (US dollars to Chinese yuan) & Straight-line depreciation \\
Ship's net weight capacity (10 thousand tons) & 6.5 \\
\end{tabular}

The cargo owner's fleet perspective Table 4.
Financial evaluation assumptions

\begin{tabular}{lcc}
\hline Fleet development plan & Building new ship & 5-year-old ship \\
\hline Ship price (10 thousand dollars) & 3,150 & 2850 \\
Total investment (100 million yuan) & 2.52 & 2.82 \\
Operating period (years) & 33 & 28 \\
Average cargo volume (tons/year) & 156.04 & 155.73 \\
Average fuel cost (10 thousand yuan/year) & 2264.04 & 2303.54 \\
Ship depreciation expense (10 thousand yuan/year) & 958 & 1,084 \\
NAV (10 thousand yuan) & 1,371 & 1,699 \\
IRR (\%) & 13.57 & 16.86
\end{tabular}

Table 5.

Economic indicators of the two fleet development plans 
MABR

7,3

250

Table 6.

Economic index of 5year-old secondhand ships at different discount rates
From the perspective of economic indicators, under the premise of an $8 \%$ discount rate, the net average value (NAV) of the two plans is greater than 0 , and the NAV and the internal rate of return (IRR) of the 5-year ship plan are greater than those of the newly built ship plan. That is, both investment schemes are feasible, but the economic indicators of the 5-year ship plan are better.

(3) Sensitivity analysis of two fleet development plans

The following further analyzes the economic sensitivity of 5 -year-old ships and new ships to different discount rates, oil prices, freight rates, ship prices and exchange rates.

- Economic sensitivity analysis of 5-year-old secondhand ships

For the 5-year-old ship, the net present value (NPV) under different discount rates and economic indicators, such as return on investment (ROI), is analyzed, as shown in Table 6.

From Table 6, we can observe that the NPV and NAV are greater than 0 when the discount rate is within the range of $8-12 \%$. The IRR reaches $16.86 \%$, and the return on investment (ROI) is $12.34 \%$. From the foregoing economic indicators, purchasing a 5 -year-old secondhand ship and putting it into operation has certain profitability.

Moreover, for the fleet development plan of purchasing a 5-year-old secondhand ship, sensitivity analysis of fuel price and freight price changes is conducted, as shown in Table 7 , and the sensitivity of ship price and exchange rate changes is analyzed in Table 8 .

In Table 7, in the most extreme case of a 15\% drop in freight rate and a $15 \%$ increase in fuel price, the IRR of the plan is still $9.42 \%$. In other cases, the IRR is greater than $8 \%$. According to Table 8, under the extreme situation that the exchange rate of the US dollar against RMB increases by $10 \%$ and the shipping price increases by $20 \%$, the IRR is still $12.23 \%$. Thus, we believe that it is economically feasible to purchase a 5 -year-old secondhand ship to increase the transport capacity of the self-owned fleet.

- Economic sensitivity analysis of building a new ship

\begin{tabular}{lrrrrr}
\hline Different discount rates & $8 \%$ & $9 \%$ & $10 \%$ & $11 \%$ & $12 \%$ \\
\hline NPV (10 thousand yuan) & 18,774 & 15,441 & 12,542 & 10,007 & 7,777 \\
NAV (10 thousand yuan) & 1,699 & 1,526 & 1,348 & 1,163 & 974 \\
IRR & & & $16.86 \%$ & & \\
Total investment (10 thousand yuan) & & & 22,817 & & \\
ROI & & & $12.34 \%$ & & \\
\hline
\end{tabular}

\begin{tabular}{lrrrrrrrrr}
\hline & & & \multicolumn{8}{c}{ Freight rate change (yuan/ton) } \\
& & & $-15 \%$ & $-10 \%$ & $-5 \%$ & $0 \%$ & $5 \%$ & $10 \%$ & $15 \%$ \\
IRR (\%) & & & 40.8 & 43.2 & 45.6 & 48.0 & 50.4 & 52.8 & 55.2 \\
\hline Fuel price fluctuation (Yuan/ & $-15 \%$ & 3,220 & 12.88 & 14.76 & 16.58 & 18.38 & 20.14 & 21.89 & 23.62 \\
ton) & $-10 \%$ & 3,409 & 12.33 & 14.23 & 16.07 & 17.87 & 19.65 & 21.4 & 23.14 \\
& $-5 \%$ & 3,599 & 11.77 & 13.69 & 15.55 & 17.37 & 19.15 & 20.91 & 22.65 \\
& $0 \%$ & 3,788 & 11.20 & 13.15 & 15.03 & 16.86 & 18.65 & 20.42 & 22.17 \\
& $+5 \%$ & 3,977 & 10.62 & 12.60 & 14.50 & 16.34 & 18.15 & 19.93 & 21.68 \\
& $+10 \%$ & 4,167 & 10.03 & 12.04 & 13.96 & 15.82 & 17.64 & 19.43 & 2.19 \\
& $+15 \%$ & 4,356 & 9.42 & 11.47 & 13.42 & 15.3 & 17.13 & 18.93 & 20.70 \\
\hline
\end{tabular}

- Economic sensitivity analysis of building a new ship
Table 7.

The influence of fuel and freight price changes on the IRR of purchasing a 5-yearold ship 


\begin{tabular}{|c|c|c|c|c|c|c|c|c|c|c|c|c|}
\hline $\operatorname{IRR}(\%)$ & & & $\begin{array}{c}-20 \% \\
2,280\end{array}$ & $\begin{array}{l}-15 \% \\
2422.5\end{array}$ & $\begin{array}{c}\text { Var } \\
-10 \% \\
2,565\end{array}$ & $\begin{array}{l}\text { ation in } \\
-5 \% \\
2707.5\end{array}$ & $\begin{array}{l}\text { hip pric } \\
0 \% \\
2,850\end{array}$ & $\begin{array}{c}(\$ 10,00 \\
5 \% \\
2992.5\end{array}$ & $\begin{array}{l}10 \% \\
3,135\end{array}$ & $\begin{array}{c}15 \% \\
3277.5\end{array}$ & $\begin{array}{l}20 \% \\
3,420\end{array}$ & $\begin{array}{r}\text { The cargo } \\
\text { owner's fleet } \\
\text { perspective }\end{array}$ \\
\hline $\begin{array}{l}\text { The } \\
\text { exchange } \\
\text { rate }\end{array}$ & $\begin{array}{r}-10 \% \\
-8 \% \\
-6 \% \\
-4 \% \\
-2 \% \\
0 \% \\
+2 \% \\
+4 \% \\
+6 \% \\
+8 \% \\
+10 \%\end{array}$ & $\begin{array}{l}5.85 \\
5.98 \\
6.11 \\
6.24 \\
6.37 \\
6.5 \\
6.63 \\
6.76 \\
6.89 \\
7.02 \\
7.15\end{array}$ & $\begin{array}{l}24.07 \\
23.51 \\
22.98 \\
22.47 \\
21.98 \\
21.51 \\
21.05 \\
20.62 \\
20.20 \\
19.79 \\
19.40\end{array}$ & $\begin{array}{l}22.56 \\
22.04 \\
21.53 \\
21.05 \\
20.59 \\
20.14 \\
19.72 \\
19.31 \\
18.91 \\
18.53 \\
18.16\end{array}$ & $\begin{array}{l}21.22 \\
20.72 \\
20.25 \\
19.79 \\
19.35 \\
18.93 \\
18.53 \\
18.14 \\
17.76 \\
17.40 \\
17.05\end{array}$ & $\begin{array}{l}20.02 \\
19.55 \\
19.09 \\
18.66 \\
18.24 \\
17.84 \\
17.46 \\
17.08 \\
16.73 \\
16.38 \\
16.05\end{array}$ & $\begin{array}{l}18.93 \\
18.48 \\
18.05 \\
17.64 \\
17.24 \\
16.86 \\
16.49 \\
16.13 \\
15.79 \\
15.46 \\
15.14\end{array}$ & $\begin{array}{l}18.42 \\
17.98 \\
17.56 \\
17.15 \\
16.77 \\
16.39 \\
16.03 \\
15.68 \\
15.35 \\
15.03 \\
14.71\end{array}$ & $\begin{array}{l}17.05 \\
16.63 \\
16.24 \\
15.86 \\
15.49 \\
15.14 \\
14.80 \\
14.48 \\
14.16 \\
13.86 \\
13.56\end{array}$ & $\begin{array}{l}16.22 \\
15.83 \\
15.45 \\
15.08 \\
14.73 \\
14.39 \\
14.06 \\
13.75 \\
13.45 \\
13.15 \\
12.87\end{array}$ & $\begin{array}{l}15.46 \\
15.08 \\
14.71 \\
14.36 \\
14.02 \\
13.70 \\
13.38 \\
13.08 \\
12.79 \\
12.50 \\
12.23\end{array}$ & $\begin{array}{r}\text { Table } 8 . \\
\text { The influence of ship } \\
\text { purchase price and } \\
\text { exchange rate } \\
\text { fluctuation on IRR }\end{array}$ \\
\hline
\end{tabular}

The economic indicators, such as NPV, under different discount rates and ROI for the newly constructed ship plan are shown in Table 9. As seen in the table, the NPV of the shipbuilding plan is greater than zero with a discount rate from $8 \%$ to $12 \%$, the IRR is $13.57 \%$ and the ROI is $11.61 \%$. Therefore, the new shipbuilding plan is also economically feasible.

Furthermore, sensitivity analysis of fuel price and freight price changes for the newly constructed ship plan is conducted, as shown in Table 10, and the sensitivity analysis of ship construction price and exchange rate changes is presented in Table 11.

According to Table 10, in the most extreme case of a 15\% drop in freight rate and a $15 \%$ increase in fuel price, the IRR of the project is still $8.17 \%$. In all cases, the project IRR is greater than $8 \%$. From Table 11 , under the extreme situation in which the exchange rate increases by $10 \%$ and the shipping price increases by $20 \%$, the IRR is $10.19 \%$. Therefore, the newly constructed ship plan also has good economic feasibility in different situations.

\begin{tabular}{|c|c|c|c|c|c|c|}
\hline Different discount rate & $8 \%$ & $9 \%$ & $10 \%$ & $11 \%$ & $12 \%$ & \\
\hline $\begin{array}{l}\text { NPV (10 thousand yuan) } \\
\text { NAV (10 thousand yuan) } \\
\text { IRR } \\
\text { Total investment (10 thousand yuan) } \\
\text { ROI }\end{array}$ & $\begin{array}{r}15,891 \\
1,371\end{array}$ & $\begin{array}{r}11,986 \\
1,140\end{array}$ & $\begin{array}{c}8,650 \\
900 \\
13.57 \% \\
25,219 \\
11.61 \%\end{array}$ & $\begin{array}{r}5,778 \\
654\end{array}$ & $\begin{array}{r}3,289 \\
403\end{array}$ & $\begin{array}{r}\text { Table 9. } \\
\text { Economic index of the } \\
\text { newly constructed ship } \\
\text { plan at different } \\
\text { discount rates }\end{array}$ \\
\hline
\end{tabular}

\begin{tabular}{lrrrrrrrrrrr}
\hline & & \multicolumn{8}{c}{ Freight rate change (yuan/ton) } \\
IRR (\%) & & & $-15 \%$ & $-10 \%$ & $-5 \%$ & $0 \%$ & $5 \%$ & $10 \%$ & $15 \%$ & \\
Fuel price fluctuation (Yuan// & $-15 \%$ & 3,220 & 10.69 & 12.05 & 13.36 & 14.62 & 15.84 & 17.02 & 18.18 & \\
ton) & $-10 \%$ & 3,409 & 10.29 & 11.68 & 13.00 & 14.27 & 15.50 & 16.70 & 17.86 & \\
& $-5 \%$ & 3,599 & 9.89 & 11.30 & 12.64 & 13.92 & 15.17 & 16.37 & 17.54 & \\
& $0 \%$ & 3,788 & 9.47 & 10.91 & 12.27 & 13.57 & 14.83 & 16.04 & 17.22 & Table 10. \\
& $+5 \%$ & 3,977 & 9.05 & 10.51 & 11.89 & 13.21 & 14.48 & 15.71 & 16.90 & The influence of fuel \\
& $+10 \%$ & 4,167 & 8.62 & 10.11 & 11.51 & 12.85 & 14.13 & 15.37 & 16.57 & and freight price \\
& $+15 \%$ & 4,356 & 8.17 & 9.70 & 11.13 & 12.48 & 13.78 & 15.03 & 16.25 & changes on IRR \\
\hline
\end{tabular}




\begin{tabular}{|c|c|c|c|c|c|c|c|c|c|c|c|c|}
\hline \multirow{4}{*}{$\begin{array}{l}\text { MABR } \\
7,3\end{array}$} & & & & & & & & & & & & \\
\hline & \multirow{3}{*}{\multicolumn{3}{|c|}{$\operatorname{IRR}(\%)$}} & \multicolumn{9}{|c|}{ Variation in ship price $(\$ 10,000)$} \\
\hline & & & & $-20 \%$ & $-15 \%$ & $-10 \%$ & $-5 \%$ & $0 \%$ & $5 \%$ & $10 \%$ & $15 \%$ & $20 \%$ \\
\hline & & & & 2,520 & 2677.5 & 2,835 & 2992.5 & 3,150 & 3307.5 & 3,465 & 3622.5 & 3,780 \\
\hline \multirow{5}{*}{252} & \multirow{11}{*}{$\begin{array}{l}\text { The } \\
\text { exchange } \\
\text { rate }\end{array}$} & $-10 \%$ & 5.85 & 18.51 & 17.51 & 16.60 & 15.78 & 15.03 & 14.34 & 13.71 & 13.12 & 12.57 \\
\hline & & $-8 \%$ & 5.98 & 17.94 & 17.15 & 16.27 & 15.46 & 14.72 & 14.04 & 13.41 & 12.83 & 12.2 \\
\hline & & $-6 \%$ & 6.11 & 17.59 & 16.82 & 15.94 & 15.14 & 14.41 & 13.75 & 13.13 & 12.56 & 12.0 \\
\hline & & $-4 \%$ & 6.24 & 17.25 & 16.49 & 15.63 & 14.84 & 14.12 & 13.46 & 12.86 & 12.29 & 11.77 \\
\hline & & $-2 \%$ & 6.37 & 16.93 & 16.17 & 15.32 & 14.55 & 13.84 & 13.19 & 12.59 & 12.04 & 11.5 \\
\hline & & $0 \%$ & 6.5 & 16.61 & 15.87 & 15.03 & 14.27 & 13.57 & 12.93 & 12.34 & 11.79 & 11.28 \\
\hline & & $+2 \%$ & 6.63 & 16.31 & 15.57 & 14.75 & 14.00 & 13.31 & 12.68 & 12.09 & 11.55 & 11.05 \\
\hline Tabl & & $+4 \%$ & 6.76 & 16.01 & 15.29 & 14.47 & 13.73 & 13.05 & 12.43 & 11.85 & 11.32 & 10.82 \\
\hline iip & & $+6 \%$ & 6.89 & 15.73 & 15.01 & 14.21 & 13.48 & 12.81 & 12.19 & 11.62 & 11.10 & 10.61 \\
\hline & & $+8 \%$ & 7.02 & 15.45 & 14.75 & 13.95 & 13.23 & 12.57 & 11.96 & 11.40 & 10.88 & 10.39 \\
\hline rate fluctuation on IRR & & $+10 \%$ & 7.15 & 15.18 & 14.49 & 13.71 & 12.99 & 12.34 & 11.74 & 11.18 & 10.67 & 10.19 \\
\hline
\end{tabular}

- Break-even analysis of the two fleet development plans

In the case of a certain discount rate, different freight rates will have different NPVs. The freight rate when the NPV is zero is the break-even rate. According to the calculation, when the discount rate is $8 \%$, the break-even freight rate for the new ship plan is 38.49 yuan/ton and that of the 5-year-old secondhand ship plan is 37.12 yuan/ton. Both of these values are far lower than the assumed freight rate of 48 yuan/ton. However, the break-even freight rate of the latter is less than that of the former, which reflects that it is better to buy a 5 -year-old secondhand ship.

\section{Conclusions}

We specifically target energy groups that have a guaranteed demand for electricity coal transportation and have considered the fleet combination model and fleet development plan of the cargo owner's fleet.

To minimize the total operating cost, an optimization model that considers volatility factors, such as freight rates and oil prices, in the shipping market is constructed to determine the best allocation ratio of the self-owned fleet and chartered fleet, and the exact solution is obtained by the CPLEX solver. Furthermore, empirical experiments are conducted based on historical data from the past five years. The results show that the optimal ratio of the selfowned fleet is $90.40 \%$. For the energy group investigated in this study, if the ratio is increased to the optimal level, the total operating cost of the fleet can be reduced by $33.98 \%$. Moreover, sensitivity analysis considering capital cost and opportunity loss is conducted to validate the effectiveness and universality of the proposed model. Therefore, for cargo owners' fleets, under the circumstances of the volatility of the shipping market, the suggested value (as an approximate value or a range) of the self-owned fleet ratio can provide a reference with a universal application scale for all cargo owners' fleets.

From the perspectives of economic and technical feasibility, we evaluate the best selfowned fleet development plan, including the best number of ships, ship type and configuration plan. To ensure the effective supply of electricity coal, the energy group should increase its capacity with a Panamax vessel of approximately 82,000 DWT. Buying a 5 -year-old secondhand ship and building a new ship both have high IRR and NAV, but the former approach is better than the latter. Therefore, under the circumstances of the shipping market in the first half of 2021, a timely investment plan to increase fleet capacity with the economic boundary conditions in the paper will result in a good ROI. Other fleet owners can refer to the conditions in the paper to make good investment decisions. 
This research still has some limitations. First, there are three modes of maritime transport capacity: self-owned mode, lease mode and joint mode. This paper considers only the first two modes, and the comprehensive consideration of the three modes may apply to some cargo ship fleets. Second, this article ignores the risks of different fleet modes and considers only the operating costs. Future research may investigate the trade-off between risk and cost. Last, only two volatility factors are considered in this paper: freight rates and oil prices. To fit with practice on a larger scale, additional volatility factors should be taken into consideration.
The cargo owner's fleet perspective

\section{References}

Alvarez, J.F., Tsilingiris, P., Engebbrethsen, E.S. and Kakalis, N.M.P. (2011), "Robust fleet sizing and deployment for industrial and independent bulk ocean shipping companies", Infor Information Systems and Operational Research, Vol. 49 No. 2, pp. 93-107.

Cigolini, R., Pero, M. and Rossi, T. (2013), "Sizing off-shore transhipment systems: a case study in maritime dry-bulk transportation”, Production Planning and Control, Vol. 24 No. 1, pp. 15-27.

Jiang, Z.F., Peng, Y.N. and Yang, Z.Z. (2019), "Renewal strategy and policy effect of dry bulk fleet under shipbreaking subsidy policy", Journal of Dalian Maritime University, Vol. 45 No. 3, pp. 17-23.

Lee, C.C. and Chiu, Y.B. (2013), "Modeling OECD energy demand: an international panel smooth transition error-correction model", International Review of Economics and Finance, Vol. 25, pp. 372-383.

Li, D.Y. and Liao, Y.L. (2018), "Spatial characteristics of heavy metals in street dust of coal railway transportation hubs: a case study in Yuanping, China", International Journal of Environment Research and Public Health, Vol. 15 No. 12, pp. 1-21.

Li, B.B., Liang, Q.M. and Wang, J.C. (2015), “A comparative study on prediction methods for China's medium- and long-term coal demand”, Energy, Vol. 93 No. 2, pp. 1671-1683.

Liu, C.M. and Sherali, H.D. (2000), "A coal shipping and blending problem for an electric utility company”, Omega, Vol. 28 No. 4, pp. 433-444.

Meng, Q., Wang, T. and Wang, S. (2015), "Multi-period liner ship fleet planning with dependent uncertainty container shipment demand", Maritime Policy and Management, Vol. 42 No. 1, pp. $43-67$.

Mon, D. and Li, Z. (2012), “A spatial analysis of China's coal flow”, Energy Policy, Vol. 48, pp. 358-368.

Ozfirat, P.M., Ozfirat, M.K. and Malli, T. (2018), "Selection coal transportation mode from the open pit mine to the thermic power plant using fuzzy analytic hierarchy process", Transport, Vol. 33 No. 2, pp. 502-509.

Sherwood, J., Bickhart, R., Murawski, E., Dhanani, Z., Lytle, B., Carbajales-Dale, P. and CarbajalesDale, M. (2020), "Rolling coal: the greenhouse gas emissions of coal rail transport for electricity generation", Journal of Cleaner Production, Vol. 259, pp. 1-11.

Sozen, A., Izgec, M.M., Kirbas, I., Kazancolu, F.T. and Tuncer, A.D. (2021), "Overview, modeling and forecasting the effects of COVID-19 pandemic on energy market and electricity demand: a case study on Turkey", Energy Sources Part A-Recovery Utilization and Environmental Effects, in press.

Tierney, K., Handali, J., Grimme, C. and Trautmann, H. (2017), "Multi-objective optimization for linear shipping fleet repositioning", International Conference on Evolutionary Multi-Criterion Optimization, pp. 622-638.

Wang, C. and Ducruet, C. (2014), "Transport corridors and regional balance in China: the case of coal trade and logistics", Journal of Transport Geography, Vol. 40, pp. 3-16.

Wang, W.Y. and Li, Z.F. (2019), "Spatial evolution of coal transportation network of China", Journal of Traffic and Transportation Engineering, Vol. 19 No. 3, pp. 166-177.

Wang, W.Y. and Li, Z.F. (2020), "Hub-and-spoke network construction of China's domestic coal transportation", Journal of Dalian Maritime University, Vol. 46 No. 1, pp. 75-88. 
MABR 7,3

\section{4}

Wang, S., Liu, Z. and Qu, X. (2016), "Minimax regret model for liner shipping fleet deployment with uncertainty demand", Transportation Research Record: Journal of the Transportation Research Board, Vol. 2549 No. 1, pp. 45-53.

Wang, C., Li, B.B., Liang, Q.M. and Wang, J.C. (2018), "Has China's coal consumption already peaked? A demand-side analysis based on hybrid prediction models", Energy, Vol. 162, pp. 272-281.

Wang, W., Wang, C. and Jin, F. (2018), "Spatial evolution of coal transportation at coastal ports in China”, Journal of Geographical Sciences, Vol. 28 No. 2, pp. 238-256.

Wu, T.H., Huang, K.I. and Chen, W. (1995), "Optimal scheduling plan for a coal shipment problem: an efficient approach”, Computers and Industrial Engineering, Vol. 29 Nos 1-4, pp. 489-493.

Xie, X.L., Tang, L. and Zhao, J.B. (2014), "Practical optimization technology for large-scale vessel fleet", China Sciencepaper, Vol. 9 No. 11, pp. 1227-1232.

Yang, Z.Z., Jiang, Z.F., Notteboom, T. and Haralambides, H.E. (2019), "The impact of ship scrapping subsidies on fleet renewal decisions in dry bulk shipping", Transportation Research Part E-Logistics and Transportation Review, Vol. 126, pp. 177-189.

$\mathrm{Yu}$, S.W. and Zhu, K.J. (2012), “A hybrid procedure for energy demand forecasting in China”, Energy, Vol. 37 No. 1, pp. 396-404.

Yu, S.W., Wei, Y.M. and Wang, K. (2012), “China's primary energy demands in 2020: prediction from an MPSO-RBF estimation model", Energy Conversion and Management, No. 61, pp. 59-66.

Yucekaya, A. (2013), "Multi-objective fuel supply for coal-fired power plants under emission, transportation and operational constraints", Energy Sources Part B-Economics Planning and Policy, Vol. 8 No. 2, pp. 179-189.

Zhu, Y. and Zhang, R. (2020), "A research on the development trend of railway coal transportation", Railway Transportation and Economy, Vol. 42 No. 4, pp. 98-103.

\section{Corresponding author}

Qi Xu can be contacted at: cogi@163.com

For instructions on how to order reprints of this article, please visit our website:

www.emeraldgrouppublishing.com/licensing/reprints.htm

Or contact us for further details: permissions@emeraldinsight.com 